\title{
A nationwide survey of the tabanid fauna of Cameroon
}

\author{
Silas L. Sevidzem ${ }^{1,2,3 *}$, Aubin A. Koumba ${ }^{2,3}$, Genevieve L. Yao-Acapovi ${ }^{4}$ and Jacques F. Mavoungou $2,3,5$
}

\begin{abstract}
Background: Tabanids are a neglected group of haematophagous dipterans despite containing 4434 species, regrouped in $>144$ genera. They are mechanical vectors of important pathogens, including viruses, bacteria and protozoa of humans and domesticated and wild animals. As it is $>50$ years since the publication of a preliminary nationwide record of the tabanids of Cameroon identified 84 species, updated information is needed. The aim of this study was to provide current data on the species composition, abundance and distribution of tabanids in the five main agro-ecological zones (AEZs) of Cameroon.
\end{abstract}

Methods: From 2015 to 2017, a systematic entomological study using Nzi, Vavoua, Biconical and Sevi traps ( $n=106)$ was conducted in 604 trapping points over 11,448 trap-days in the five main AEZs of Cameroon.

Results: A total of 25,280 tabanids belonging to 25 species were collected, including eight species not previously documented in Cameroon, namely Tabanus latipes (1 female), Tabanus ricardae (1 female), Tabanus fasciatus (32 females and 6 males), Haematopota pluvialis (18 females), Haematopota decora (19 females and 3 males), Haematopota nigripennis (18 females), Chrysops distinctipennis (47 females and 5 males) and Ancala fasciata (34 females and 7 males). The distribution maps of the newly identified tabanids differed between AEZs, with most tabanids collected from the Guinean savanna. The highest apparent density of tabanids was recorded in the Sudan Savanna region, and the mean apparent densities of species with sites was statistically significantly different (Student t-test: $2.519, d f=24, P=0.019$ ). The highest species diversity was found in the rainforest.

Conclusions: This study increased the list of tabanids recorded in Cameroon from 84 species in the preliminary record to 92 species, with most of the newly identified species occurring in the Guinea Savanna AEZ. The high diversity and abundance of tabanids in the livestock/wildlife interface areas of the rain forests and Sudan Savanna AEZs, respectively, suggest risk of mechanical transmission of pathogens. Investigations of the microbiota of tabanids in the different AEZs to define their role as disease vectors are proposed.

Keywords: Tabanids, Checklist, Abundance, Agro-ecological zone, Distribution maps, Cameroon

\section{Background}

Tabanids (Diptera, Tabanidae) form one of the largest groups of haematophagous flies with about 4434 species $[1,2]$ and more than 144 genera [3-7]. These flies are well known due to three medical and veterinary important

*Correspondence: sevidzem.lendze@gmail.com

1 Programme Onchocercoses Field Station Laboratory, Ngaoundéré, Cameroon

Full list of author information is available at the end of the article taxa, namely horse flies (Tabanus spp.), deer flies (Chrysops spp.) and clegs (Haematopota spp.). Tabanids inflict direct effects, such as nuisance and painful bites leading to blood loss, stress and weight loss of the affected host, and indirect effects by transmitting major pathogenic agents, including bacteria, viruses, protozoa and helminths [8-11], mechanically [12, 13]. The major bloodmeal hosts of tabanids are humans, ruminants and wild animals $[10,14]$. The consequence of their blood-feeding trait is the mechanical transmission of one of the most original author(s) and the source, provide a link to the Creative Commons licence, and indicate if changes were made. The images or other third party material in this article are included in the article's Creative Commons licence, unless indicated otherwise in a credit line to the material. If material is not included in the article's Creative Commons licence and your intended use is not permitted by statutory regulation or exceeds the permitted use, you will need to obtain permission directly from the copyright holder. To view a copy of this licence, visit http://creativecommons.org/licenses/by/4.0/. The Creative Commons Public Domain Dedication waiver (http://creativeco mmons.org/publicdomain/zero/1.0/) applies to the data made available in this article, unless otherwise stated in a credit line to the data. 
important cattle diseases in sub-Saharan Africa (SSA), namely African animal trypanosomiasis [8, 10, 15-18], in addition to the biological transmission of Loa loa filariasis $[19,20]$. The importance of studying tabanids in relation to the mechanical transmission of pathogenic trypanosomes was emphasised at the 1948 African Conference on Tsetse and Trypanosomiasis in Brazzaville [21]. However, despite the importance of tabanids, they are a neglected subject of research [10,22].

Tabanids of central Africa and other Ethiopian regions are either misidentified or poorly known and this applies in Cameroon. Apart from preliminary studies that reported 62 [21] and 84 [23] species respectively, there appear to have been no updates on their checklist and distribution. A survey in the Central African Republic indicated that 54 to 64 species constituted the tabanid fauna of this country [24]. The updated checklist of tabanids of the Ivory Coast reported the occurrence of 70 species [25], whereas 49 tabanid species are found in Algeria [26, 27] as confirmed in a recent update [28]. Moreover, other publications provided current information on tabanids of Kenya [29], East Africa (Uganda, Tanzania and Kenya) [30] and Gabon [18, 31, 32]. However, in Cameroon, apart from previously mentioned studies $[21,23]$, other reports only presented a scanty record in the Sudan savanna [33, 34]. In this context, the present study was aimed to update information on the diversity, abundance and distribution of tabanids in the main AEZs of Cameroon.

\section{Methods}

\section{Description of collection sites}

The study zones consisted of the five main AEZs of Cameroon (Fig. 1). The geographical coordinates and climatic characteristics of the different AEZs are described in Table 1.

\section{Entomological field surveys}

Tabanid trapping was conducted simultaneously in all five AEZs for 3 years (2015-2017) using different trap types, including Nzi, Vavoua, Biconical and Sevi traps. Nzi, Vavoua and Biconical traps have been used to catch tabanids in previous studies carried out in Cameroon [35, 36], whereas the Sevi trap is a modification of the malaise (René Malaise) and Canopy traps [37]. It was designed by the first author (SL Sevidzem) in Ngaoundere, tested by the Special Mission for Tsetse flies Eradication (MSEG) team in the tsetse fly-infested region of North Cameroon and confirmed as a trap for tabanids [33]. A description of the Sevi trap is provided in Additional file 1: Text 1. The same number of traps and types were not deployed in the five sampled AEZs due to differences in topography, limited number of traps/types and limitations in the

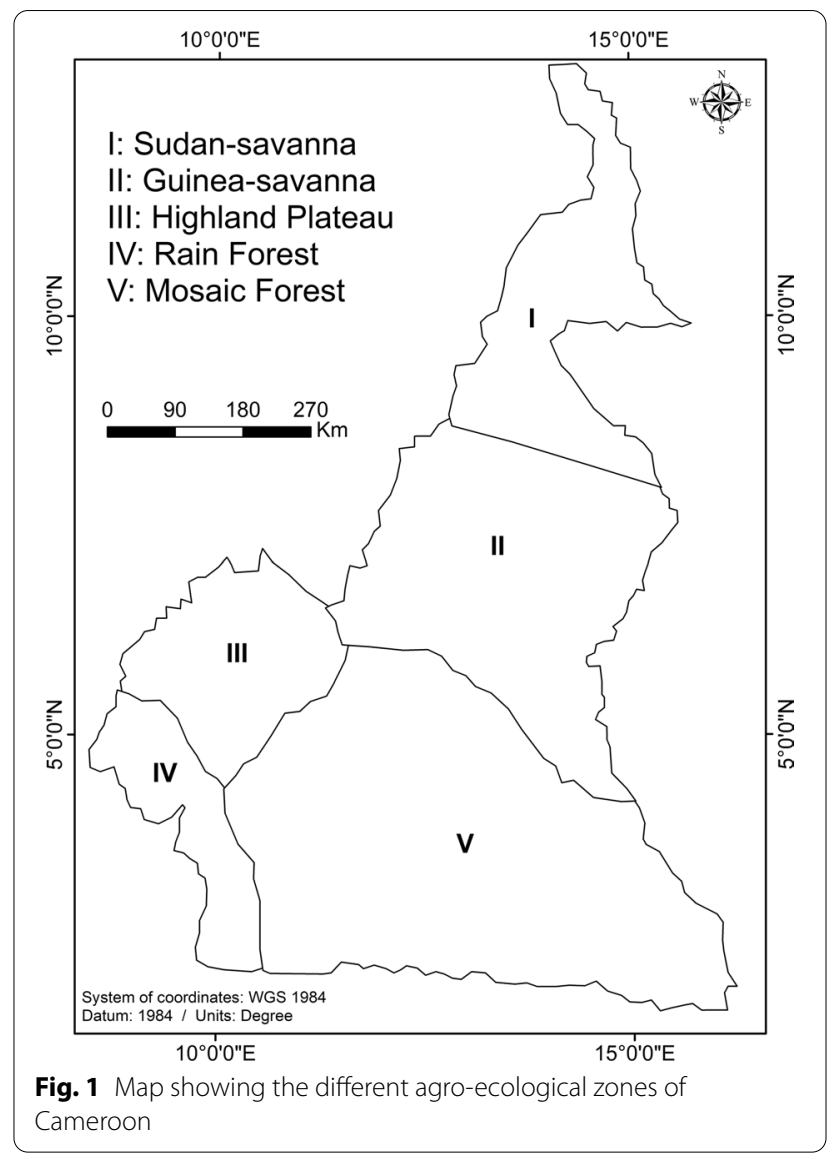

number of personnel to monitor the traps. The geolocation of trapping points was conducted using a Global Positioning System (GPS) handset (GPS eTrex ${ }^{\circledR}$; Garmin [Europe] Ltd., Southampton, UK). The trapping effort, defined as the number of traps multiplied by the number of trapping days (trap-days), was recorded. The present study was conducted within 108 days using 106 traps, resulting in a trapping effort of 11,448 trap-days.

\section{Sudan Savanna of the Far North region}

The study in the Sudan Savanna of the Far North region was carried out using 20 Nzi traps [38] in the following sites: Kalang, Kainide, Diddel tanne, Doulam and Yanga. The traps were set in potential tabanid breeding areas, such as in marshy areas around livestock drinking points, in open grass savanna that represented livestock grazing spots and in gallery forests. Trapping was conducted during 3 consecutive days per month throughout the study period. Traps were set and activated in the morning $(08: 00 \mathrm{~h})$ and cages emptied in the evening $(06: 00 \mathrm{~h})$.

\section{Sudan Savanna in the North region}

Trapping in the Sudan Savanna in the North region was carried out using a total of 39 traps (25 Vavoua [39], 
Table 1 The surveyed agro-ecological zones in Cameroon with their geographical coordinates and climatic characteristics

\begin{tabular}{|c|c|c|c|c|c|}
\hline SN & Agro-ecological zone & Study region & GPS coordinates & Altitude ( $m$ a.s.l.) & Climatic conditions of fly collection sites \\
\hline \multirow[t]{4}{*}{ । } & \multirow[t]{4}{*}{ Sudan Savanna } & \multirow[t]{2}{*}{ Far North } & $10^{\circ} 775^{\prime} \mathrm{N}$ & \multirow[t]{2}{*}{304} & \multirow{4}{*}{$\begin{array}{l}\text { Sudano-sahelian climate with two seasons (rainy and dry). Average } \\
\text { monthly temperature is } 28^{\circ} \mathrm{C} \text {. Rainfall is } 400-1200 \mathrm{~mm} / \text { year }\end{array}$} \\
\hline & & & $14^{\circ} 917^{\prime} \mathrm{E}$ & & \\
\hline & & \multirow[t]{2}{*}{ North } & $7^{\circ} 77796^{\prime} \mathrm{N}$ & \multirow[t]{2}{*}{545} & \\
\hline & & & $14^{\circ} 929^{\prime} \mathrm{E}$ & & \\
\hline \multirow[t]{2}{*}{$\|$} & \multirow[t]{2}{*}{ Guinea Savanna } & \multirow[t]{2}{*}{ Adamawa } & $7^{\circ} 00334^{\prime} \mathrm{N}$ & \multirow[t]{2}{*}{1000} & \multirow{2}{*}{$\begin{array}{l}\text { Sudanese climate type with average monthly temperature of } 20-26^{\circ} \mathrm{C} \text {. } \\
\text { Rainfall is } 1500 \mathrm{~mm} / \text { year }\end{array}$} \\
\hline & & & $13^{\circ} 01^{\prime} \mathrm{E}$ & & \\
\hline \multirow[t]{2}{*}{ III } & \multirow[t]{2}{*}{ Highland Plateau } & \multirow[t]{2}{*}{ North-west } & $5^{\circ} 92523^{\prime} \mathrm{N}$ & \multirow[t]{2}{*}{900} & \multirow{2}{*}{$\begin{array}{l}\text { Cold climate with mean monthly temperature of } 19^{\circ} \mathrm{C} \text {. Rainfall is } \\
1500-2000 \mathrm{~mm} / \text { year }\end{array}$} \\
\hline & & & $10^{\circ} 009^{\prime} \mathrm{E}$ & & \\
\hline \multirow[t]{2}{*}{ IV } & \multirow[t]{2}{*}{ Rainforest } & \multirow[t]{2}{*}{ Littoral } & $3^{\circ} 23333^{\prime} \mathrm{N}$ & \multirow[t]{2}{*}{35} & \multirow{2}{*}{$\begin{array}{l}\text { Very humid, hot and variable equatorial climate with average monthly } \\
\text { temperature between } 22 \text { and } 29^{\circ} \mathrm{C} \text {. Rainfall is } 2500-4000 \mathrm{~mm} / \text { year }\end{array}$} \\
\hline & & & $9^{\circ} 567^{\prime} \mathrm{E}$ & & \\
\hline \multirow[t]{2}{*}{ V } & \multirow[t]{2}{*}{ Mosaic forest } & \multirow[t]{2}{*}{ East } & $6^{\circ} 23333^{\prime} \mathrm{N}$ & \multirow[t]{2}{*}{890} & \multirow[t]{2}{*}{ Guinean climate type (hot and humid). Rainfall is $1500-2000 \mathrm{~mm} /$ year } \\
\hline & & & $13^{\circ} 25^{\prime} \mathrm{E}$ & & \\
\hline
\end{tabular}

$\mathrm{SN}$, Site number

10 Biconical [40], 2 Nzi [38], 2 Sevi [33]) in three sites: Mbele, Zone 27 and Zone 26. Trapping sites were mostly beside the Game Reserve, beside the river and at livestock grazing spots. Traps were activated in the morning (08:00 $\mathrm{h})$ and their cages emptied every evening $(06: 00 \mathrm{~h})$ for 3 consecutive days per month throughout the study period.

\section{Rainforest of the Sanaga-Maritime}

In the rainforest of Sanaga-Maritime, trapping sites consisted of the abattoir (open forest), palm oil plantation (open forest with mainly tall palm trees and > 50 N'Dama cattle) and around the game reserve (humid and closed forest with tall canopy trees). A total of 18 traps were used: Biconical $(n=6)$, Vavoua $(n=6)$ and Nzi $(n=6)$. The traps were set in the morning $(06: 00 \mathrm{~h})$ and emptied every evening $(06: 00 \mathrm{~h})$ for 3 consecutive days per month throughout the study period.

\section{Guinea Savanna of the Adamawa plateau}

The trapping sites in the Guinea Savanna zone consisted of Velambai (Lake Djalingo with open grass savanna), Mbidjoro (open grass savanna, forest-savanna mosaic) and Vina du Sud (Vina River with gallery forest). The trapping points were in villages with intensive cattle breeding activities. As in the rainforest of the Sanaga, a total of 18 traps were used: Biconical $(n=6)$, Vavoua $(n=6)$ and Nzi $(n=6)$. The traps were set in the morning $(07: 00 \mathrm{~h})$ and their cages emptied every evening $(06: 00 \mathrm{~h})$ for 3 consecutive days per month throughout the study period.

\section{Mosaic forest in the East region}

The survey in the mosaic forest in the East region was carried out using a total of six traps: Nzi $(n=3)$ and Vavoua $(n=3)$ traps. The traps were set in three environments: gallery forest, overnight cattle corrals and river banks (watering point for cattle). These three biotopes were identified in four sites: Minali, Oudou, Camp Général and Gabong of the Société de Développement et d'Exploitation des Productions Animales (SODEPA). The trapping points were all on the SODEPA ranch which is a public structure involved in intensive cattle production activities. The trapping cages were emptied after $24 \mathrm{~h}$ on 3 consecutive days per month throughout the study period.

\section{Highland Plateau of the North-west region}

In the Highland Plateau of the North-west region, five Biconical traps were set at livestock drinking points and grazing areas in the following sites: Bali Top Quarters, Saphery, Babah, Njinki, Tchaboutchou, Munam and Ntchuobo. Flies were collected from the traps each day before nightfall $(06: 00 \mathrm{~h})$ for 3 consecutive days per month throughout the study period.

\section{Fly identification}

All specimens were conserved in ethanol [41] and identified using a stereo microscope (Carl Zeiss ${ }^{\mathrm{TM}}$ STEMI 2000-C; Carl Zeis Microscopy GmbH, Jena, Germany). The identification of tabanid flies was made following published morphological identification keys [42-44]. The species recorded by Ovazza et al. [23] and used in this present study were rewritten following Chainey and Oldroyd [45].

\section{Sex determination}

The sex of newly identified tabanid specimens was determined using published criteria [43], where females naturally possess a larger inter-ocular width than their male counterparts. 


\section{Determination of abundance}

The abundance of trapped tabanids was translated as their apparent density per trap, reported as the number of flies per trap per day [18] as follows:

$$
\mathrm{ADT}=\frac{\mathrm{NTC}}{\mathrm{NT} \times \mathrm{ND}}
$$

where ADT is the apparent density per trap, NTC is the number of tabanids captured, NT is the number of traps and ND is the number of trapping days.

\section{Statistical analyses}

Field survey records were completed in Access 2013 (Microsoft Corp., Redmond, WA, USA) databases and joined to the location shape files produced from gpx flies from GPS handsets in ArcMap ${ }^{\mathrm{TM}}$ version 10.1 Geographic Information System (GIS) software (Environmental Systems Research Institute, West Redlands, CA, USA). Data were analysed using the JASP 0.13.0.0 statistical software [46]. The Student t-test was used to compare the mean ADT of tabanid species with sites of the different AEZs, with significance set at $P<0.05$.

\section{Results}

\section{Distribution of tabanids in the study sites}

The present study was conducted from 2015 to 2017 at 25 sites in the five major AEZs of Cameroon, with a total of 604 trapping points (Fig. 2). A total of 25,280 tabanid specimens were collected during the study period, with 25 identified species regrouped under five genera (Tabanus, Chrysops, Haematopota, Ancala and Atylotus) which were in turn members of three tribes: Tabanini, Chrysopini and Haematopotini. At the genus level, members of genera Haematopota, Ancala, Chrysops and Tabanus were encountered more often in the mosaic forest/rainforest than in the savanna, whereas members of genus Atylotus were only encountered in the savanna and never trapped in the forest. Chrysops longicornis was the only Chrysops species that was identified in both forest and savanna collections, with the other Chrysops either restricted to the forest $(C$. silacea, $C$. dimidiata, $C$. funebris) or to the savanna ( $C$. distinctipennis). Haematopota decora and Ancala fasciata were found in both forest and savanna collections, whereas Atylotus agrestis was restricted to sites in the Guinea Savanna and Sudan Savanna. Only Tabanus taeniola was caught in all the study sites (Additional file 2: Table S1).

\section{The abundance of tabanids with study sites}

The species of tabanids caught in the different sites recorded highest abundance in some sites as compared to others. Highest ADT occurred at Diddel Tanne in the Sudan savanna of the Far North region, with such dominance caused by Atylotus agrestis (136.25 flies per

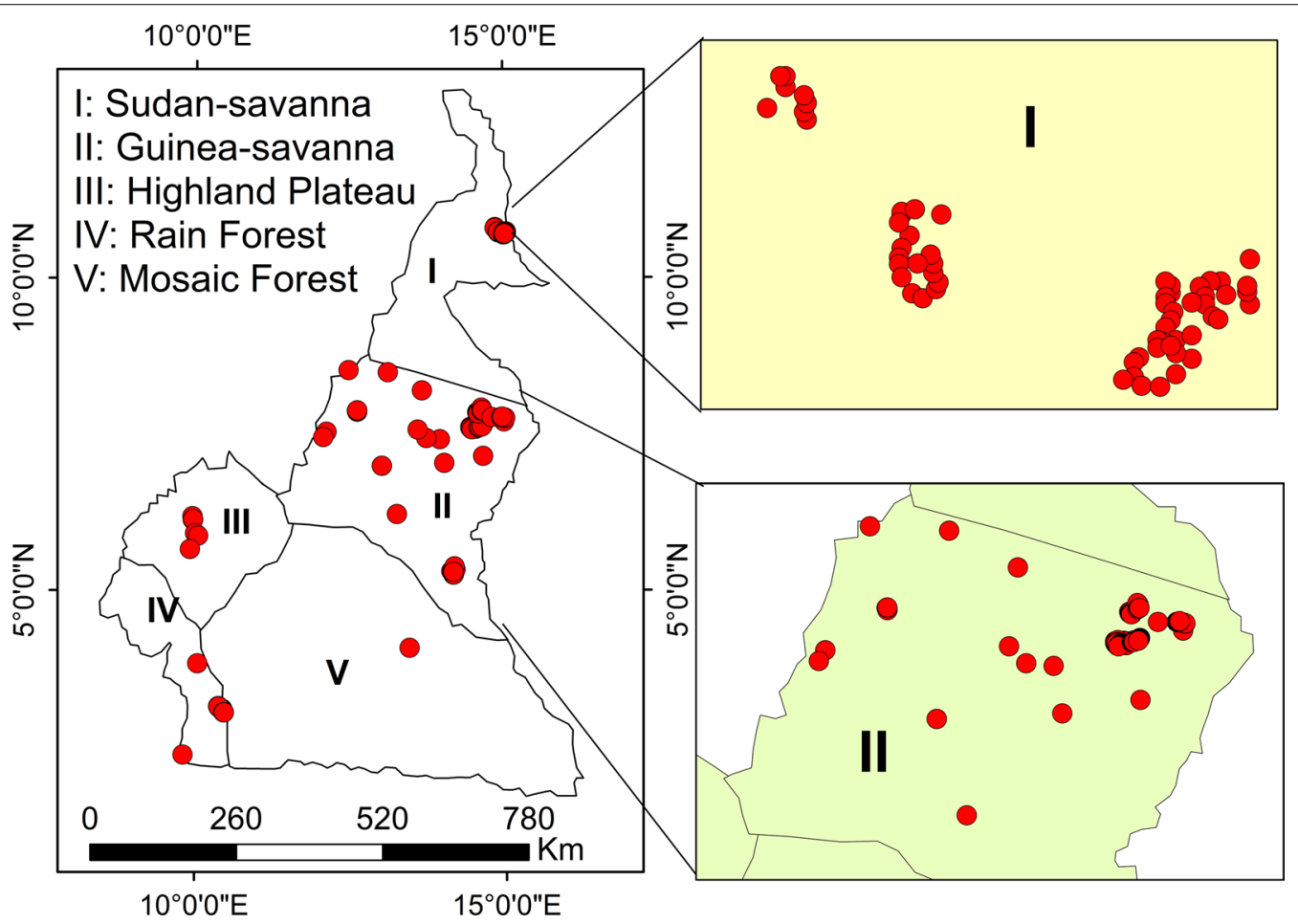

Fig. 2 Map showing the trapping points in the study zones of Cameroon 
trap per day $(\mathrm{f} / \mathrm{t} / \mathrm{d}))$. Lowest ADT was recorded in most sites in the plateau highland of the North West region (Additional file 3: Table S2). However, the mean ADTs of tabanid species with sites was statistically significantly different (Student t-test: 2.519, $d f=24, P=0.019$ ).

\section{Species diversity in the study sites}

The site with highest species diversity was the palm oil plantation (13 species) located in Mouanko around the Douala-Edea Zone (DEZ) in the rainforest, followed by Vina du Sud (12 species), a riverine-gallery forestsavanna mosaic site. Sites at which the least number of species (1 species) was identified in collections were: Kainide and Kalang sites (savanna of the Far North region) and in the Bali Top Quarters (BTQ), Saphery, Babah, Njinki, Tchaboutchou, Munam and Ntchuobo sites in the Highland Plateau of the North-west region (Fig. 3).

\section{Checklist of the Tabanidae of Cameroon}

Information on the nationwide zoogeographical distribution of tabanids in Cameroon was last updated over half a century ago, with 84 species reported to occur in Cameroon [23]. Taxonomically, tabanids from the reviewed data sets (84 species) plus those from the present study ( 25 species, including 8 new species and 17 species reported earlier [23]) belong to three subfamilies: Tabaninae, Pagoniinae and Chrysopinae. The species are placed in 15 genera (92 species): Hippocentrum (2 spp.), Haematopota (19 spp.), Ancala (3 spp.), Euancala (1 sp.), Atylotus (3 spp.), Philoliche (3 spp.), Chrysops (9 spp.), Sphecodemyia (1 sp.), Thriambeutes (1 sp.), Jashinea (1 sp.), Tabanocella (3 spp.), Tabanus (43 spp.), Thaumastocera (1 sp.), Hybromitra (1 sp.) and Mesomyia (1 sp.). These genera belong to six tribes: Bouvieromyini, Rhinomyzini, Chrysopini, Philolichini, Tabanini and Haematopotini (Additional file 4: Table S3).

The recent surveys (2015-2017) led to the identification of eight species that were not present in the list of tabanids of the preliminary survey and increased the list of tabanids occurring in Cameroon to 92. The collection sites as well as the distribution maps of the eight recently identified species are described in the following sections.

\section{Tabanus latipes}

Only one female of this species was caught using a Nzi trap set in the marshy land of the abattoir $\left(3^{\circ} 83333^{\prime} \mathrm{N}\right.$, $\left.10^{\circ} 05^{\prime} \mathrm{E}\right)$ in Mouanko in the rainforest of the DEZ of Cameroon (Fig. 4a).

\section{Tabanus ricardae}

Only one female of this species was caught by a Nzi trap set in the marshy cattle grazing field around Lake Djalingo $\left(7^{\circ} 42667^{\prime} \mathrm{N}, 13^{\circ} 945^{\prime} \mathrm{E}\right)$ of Velambai in the Sudan Savanna (Fig. 4b).

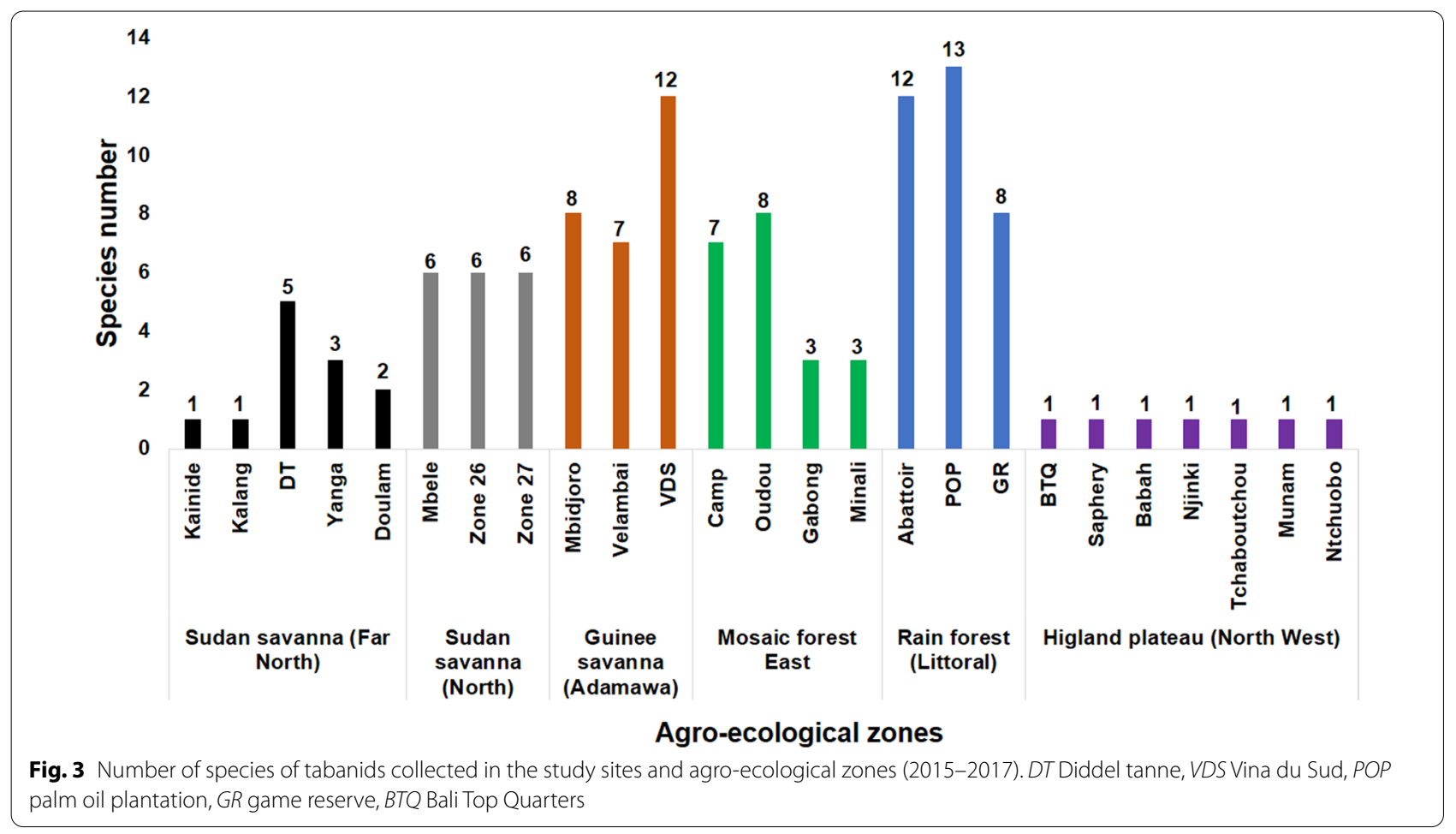



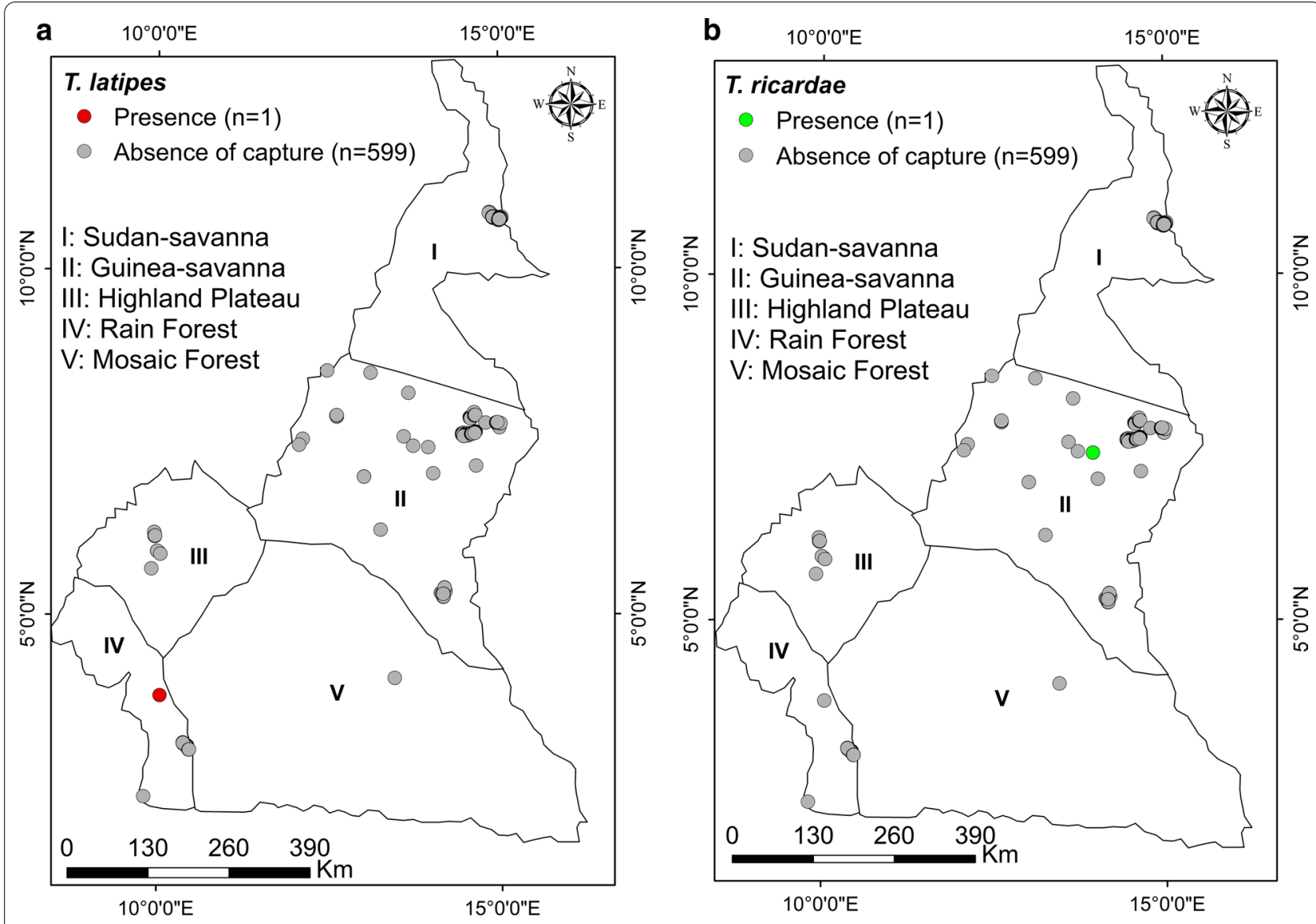

Fig. 4 Distribution map of Tabanus latipes (a) and Tabanus ricardae (b)

\section{Tabanus fasciatus}

Individuals (32 females and 6 males) of this species were caught with a Nzi trap set in the gallery forest $\left(7^{\circ} 00,334^{\prime} \mathrm{N}, 13^{\circ} 01^{\prime} \mathrm{E}\right)$ of the Sudan Savanna of Adamawa, in the Camp site and Oudou, Gabong and Minali sites of the SODEPA ranch $\left(4^{\circ} 0833^{\prime} \mathrm{N}, 13^{\circ} 45^{\prime} \mathrm{E}\right)$ of Ndokayo in the mosaic savanna (Fig. 5a).

\section{Haematopota pluvialis}

Only females $(n=18)$ of this species were caught with Nzi traps set in the mosaic forest $\left(5^{\circ} 33972^{\prime} \mathrm{N}, 14^{\circ} 188^{\prime} \mathrm{E}\right)$ precisely in Gabong of the East region (Fig. 5b).

\section{Haematopota decora}

Members of this species (19 females and 3 males) were caugh with Nzi and Vavoua traps in the savanna of Adamawa, more precisely in Galim $\left(7^{\circ} 00334^{\prime} \mathrm{N}\right.$, $\left.13^{\circ} 01^{\prime} \mathrm{E}\right)$, Velambai $\left(7^{\circ} 42667^{\prime} \mathrm{N}, 13^{\circ} 945^{\prime} \mathrm{E}\right)$ and Mbidjoro $\left(7^{\circ} 44778^{\prime} \mathrm{N}, 13^{\circ} 726^{\prime} \mathrm{E}\right)$ (Fig. 6a).

\section{Haematopota nigripennis}

Only females $(n=18)$ of this species were caught with Nzi traps set in Gabong of the mosaic savanna of SODEPA ranch $\left(4^{\circ} 0833^{\prime} \mathrm{N}, 13^{\circ} 45^{\prime} \mathrm{E}\right)$ (Fig. 6b).

\section{Chrysops distinctipennis}

This species was caught (47 females and 5 males) using Nzi traps set in the Guinea Savanna of Adamawa $\left(7^{\circ} 00335^{\prime} \mathrm{N}, 13^{\circ} 01^{\prime} \mathrm{E}\right)$ and in the North and Far North regions of the Sudan Savanna $\left(7^{\circ} 77,115^{\prime} \mathrm{N}, 14^{\circ} 983^{\prime} \mathrm{E}\right)$ (Fig. 7a).

\section{Ancala fasciata}

This species was caught (34 females and seven males) using Nzi traps set in some sites in the rainforest (palm oil plantation $\left[3^{\circ} 23333^{\prime} \mathrm{N}, 9^{\circ} 567^{\prime} \mathrm{E}\right.$ ) and abattoir $\left.\left[3^{\circ} 83333^{\prime} \mathrm{N}, 10^{\circ} 05^{\prime} \mathrm{E}\right]\right)$ in the DEZ, the Guinea Savanna $\left(7^{\circ} 00335^{\prime} \mathrm{N}, 13^{\circ} 01^{\prime} \mathrm{E}\right)$ and the mosaic savanna $\left(5^{\circ} 25694^{\prime} \mathrm{N}\right.$, $\left.14^{\circ} 155^{\prime} \mathrm{E}\right)$ (Fig. 7b). 

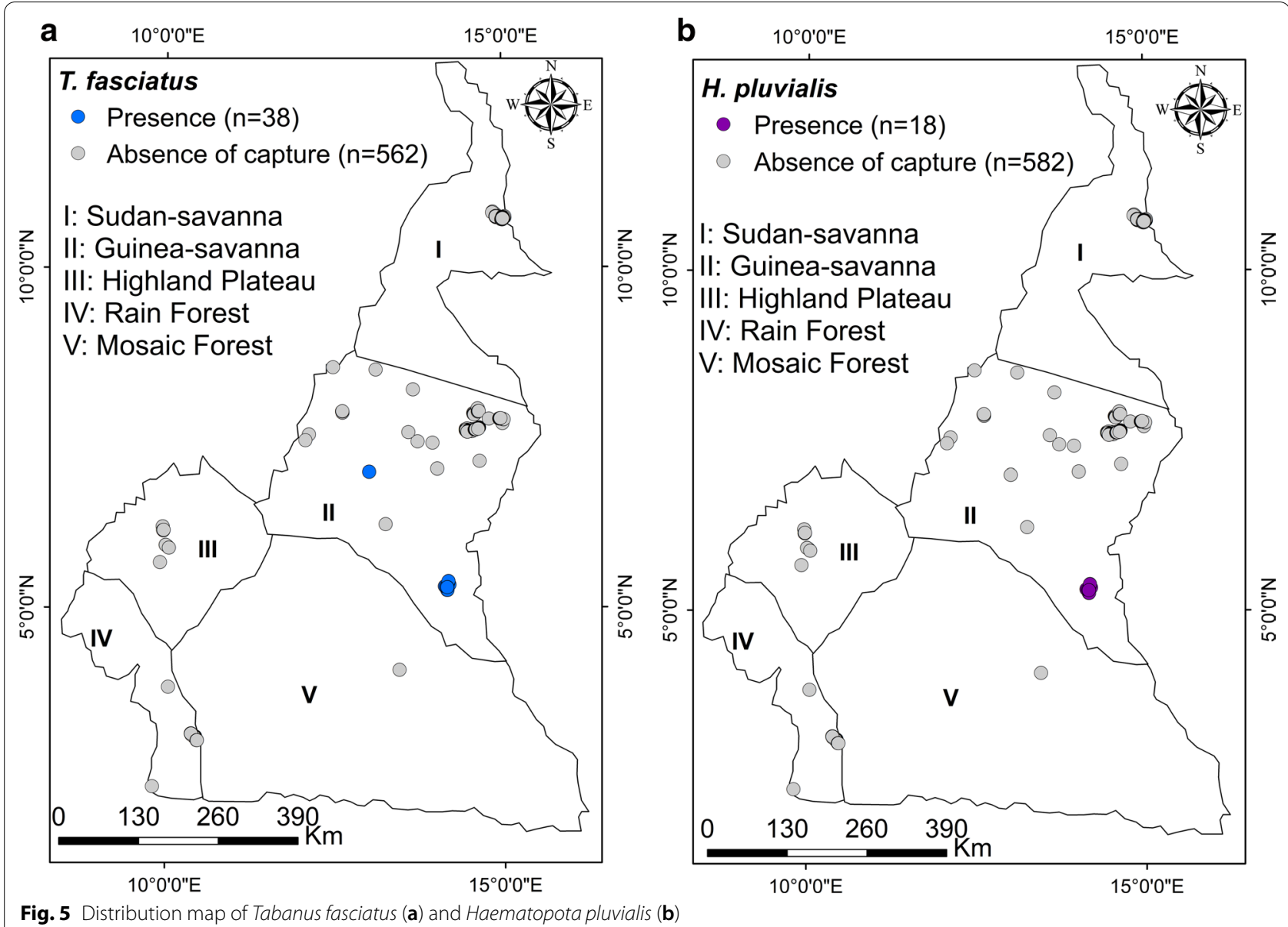

Fig. 5 Distribution map of Tabanus fasciatus (a) and Haematopota pluvialis (b)

\section{Discussion}

These surveys, conducted from 2015 to 2017, led to the identification of 25 tabanid species, much fewer than the 84 species recorded in the preliminary study of 1970 [23]. Of these 25 species, 17 were already known and the other eight had not been previously recorded in Cameroon, including T. latipes, T. ricardae, T. fasciatus, $H$. pluvialis, $H$. decora, $H$. nigripennis, $C$. distinctipennis and $A$. fasciata. The new species records increase the list of tabanids identified in Cameroon to 92 species, which is higher than that reported in other countries within the Afro-tropical region, including the Central African Republic [24], Ivory Coast [25], Algeria [26-28], Kenya [29, 30], Zambia [17], South Africa [17], Nigeria [47], Uganda and Tanzania [30], Congo [48], Liberia [49] and Gabon [18, 31, 32]. The higher number of species in the preliminary survey compared to this present study could be due to several factors, including the limited number of sampled sites $(n=25)$ in the different AEZs in the current study compared to several $(>25)$ sites in the preliminary study, the use of sweep nets in the preliminary study compared to tsetse traps in the present study and ecological changes that have influenced fly distribution and densities.

The higher number of tabanid species in Cameroon compared to that of the other countries of the Afrogeographical region likely reflects the presence of more diverse AEZs contributing to the successful development and survival of several species of tabanids. The newly recorded tabanid species of Cameroon are present in neighbouring countries of the Central and West African subregions [17, 18, 25, 31, 47]. A review on the genus Chrysops of Africa with a focus on Cameroon [20] mentioned only the occurrence of C. silacea and C. dimidiata, whereas our survey revealed five species, notably C. distinctipennis, C. longicornis, C. funebris, C. silacea and $C$. dimidiata. One possible reason for the previous scanty record of the species of this genus [20] may be that the earlier entomological surveys were limited to the forest regions of Cameroon, where C. silacea and $C$. dimidiata are omnipresent. Interestingly, the 1955 report on the presence of five species of Chrysops [21], notably C. dimidiata, C. silacea, C. funebris, C. longicornis and C. stigmaticalis, was conducted in the same study areas 


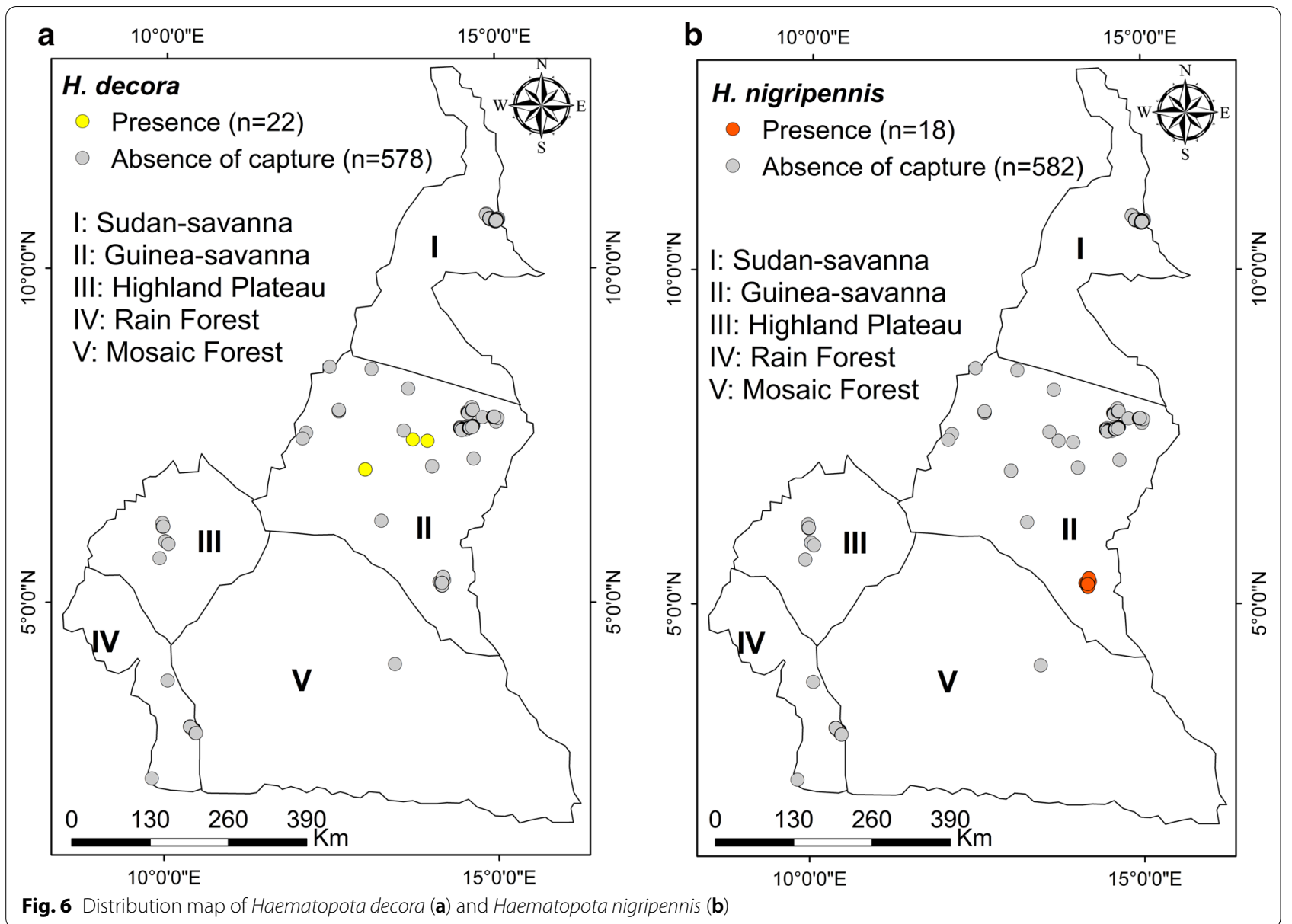

as those in the review on the genus Chrysops [20]. However, neither of these reports identified C. distinctipennis, a species recorded in the Guinean Savanna ecozones of Cameroon in our current study.

From the eight newly recorded tabanid species of Cameroon, only $H$. pluvialis is a Palaearctic species. Haematopota pluvialis inhabits various types of biotopes but is particularly very common near water and on foggy biotopes where the larvae live $[51,52]$. Haematopota pluvialis is the most common tabanid species in Europe $[51,53]$. Females actively attack humans and animals, mostly in the evening and in cloudy and showery weather [51]. The flight activity of $H$. pluvialis mostly depends on the relative humidity, but air temperature also had a great effect [52]. The flight period for this species mostly extends from late May to the beginning of October in some parts of Europe, with maximal flight activity occurring in July and August $[51,52]$.

Tabanus taeniola was the most abundant species in the forest and savanna, likely reflecting the environmental conditions favourable to this species, with similar favourable conditions frequently reported in the collections of other authors in the Afro-geographical zone [15, 18, 33, $50,54]$. Further, the highest tabanid mean apparent density was recorded in the Sudan Savanna AEZ, a finding similar to that presented in the 2020 report of the MSEG $[34,55]$, indicating the apparent absence of tsetse flies in this region and the high apparent densities of tabanids. This highest abundance of tabanids in sites of the Far North region of the country is likely due to this area being a major cattle-rearing region of Cameroon [56, 57] as well as containing the Waza Park that harbours diverse and high numbers of domestic and wild animals that can serve as blood-meal hosts for this fly group. The presence of cattle and wild animal hosts, plus the conducive environmental conditions of this region, presumably favours the development and survival of tabanids.

The highest tabanid species diversity was recorded in the rainforest of the DEZ in comparison to the other AEZs. The highest number of species $(n=13)$ was also recorded in the rainforest compared with the other sampled AEZs. One likely factor accounting for this high abundance and diversity could be the favourable environmental conditions of this AEZ for several species 


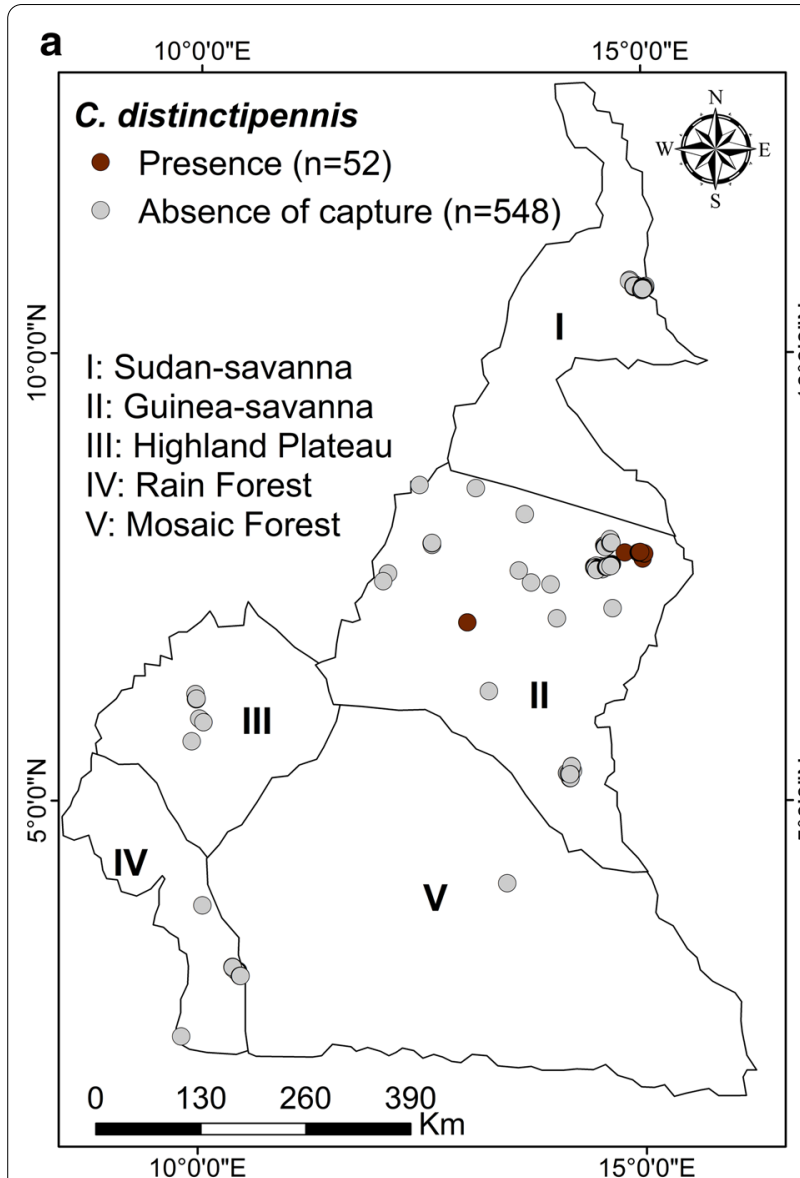

Fig. 7 Distribution map of Chrysops distinctipennis (a) and Ancala fasciata (b)

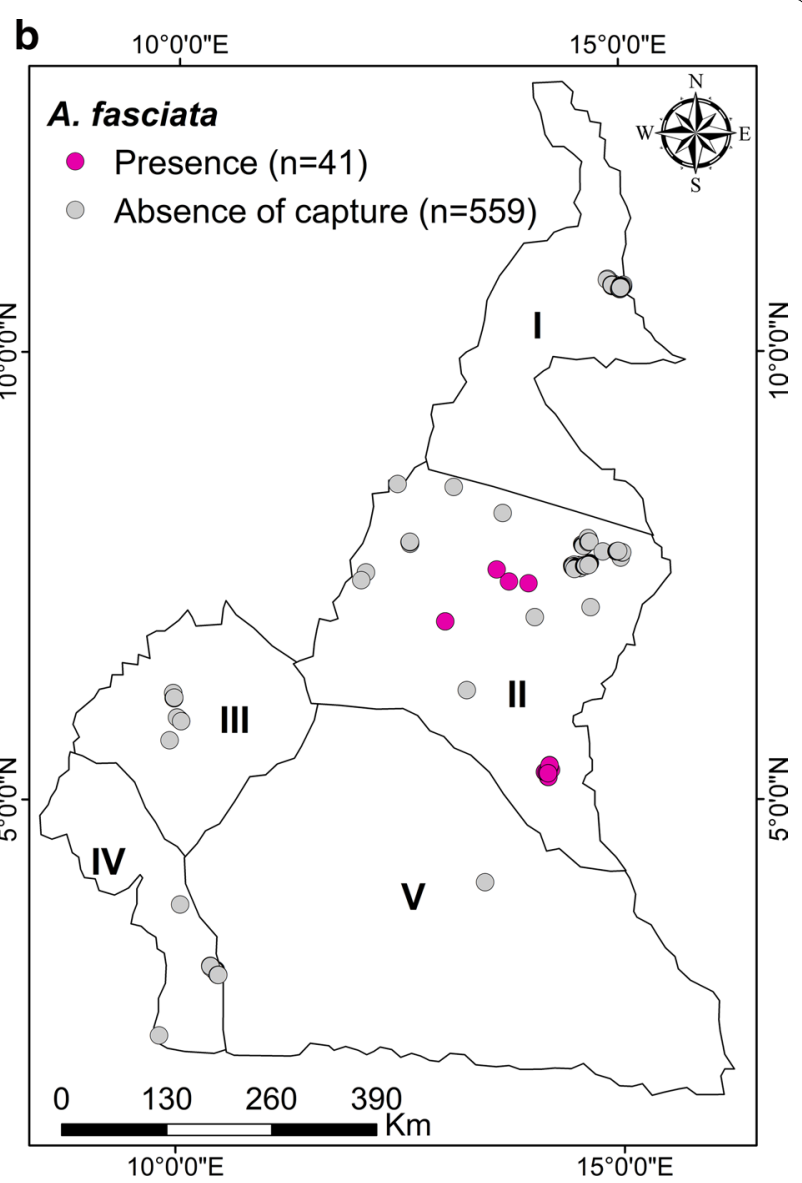

of tabanids and because it was the least anthropized of the sampling sites, with wild animals and N'Dama cattle serving as blood-meal hosts and providing a suitable environment for tabanid development and survival [31]. The rainforest sites consisted of tall palm trees equally interspaced to provide high luminosity and canopy trees for shelter, rivers and abundant marshy land for breeding; the presence of palm trees has been reported to harbour high numbers of different species of tabanids [23]. The 1955 study in forest areas of South Cameroon indicated the abundance of breeding sites for female tabanids that favoured their proliferation in this zone [21].

\section{Conclusions}

The present study registered 25,280 tabanid specimens that were regrouped under 25 species. Of the 25 species recorded, eight had not been included in the preliminary list of Tabanidae of Cameroon previously published [23], notably $T$. latipes, $T$. ricardae, T. fasciatus, $H$. pluvialis, $H$. decora, $H$. nigripennis, $C$. distinctipennis and A. fasciata. Identification of these novel species has increased the number of Tabanidae occurring in the country from 84 to 92 . The newly identified species were mostly found in the Guinean Savanna. The highest Tabanidae apparent density was recorded in the Sudan Savanna region whereas the highest species diversity was noted in the rainforest of the DEZ. The high diversity and abundance of Tabanidae in the livestock/wildlife interface areas of the rainforest and Sudan Savanna AEZs, respectively, strongly suggests a risk for the mechanical transmission of dangerous pathogens. Future investigations on this group focussed on studying the microbiota they harbour are proposed, with the aim to establish their potential epizootiological role in the transmission of diseases in the different AEZs.

\section{Abbreviations}

CARPA: Center for Support to Research and Pastoralism; IRAD: Agricultural Research Institute for Development; MINEPIA: Ministry of Livestock Fisheries and Animal Industries; MSEG: Special Mission for Tsetse flies Eradication. 


\section{Supplementary Information}

The online version contains supplementary material available at https://doi. org/10.1186/s13071-021-04894-0.

Additional file 1: Text 1. Detail presentation of the Sevi trap.

Additional file 2: Table S1. Species distribution of tabanids in different sites and bioclimatic zones of Cameroon (2015-2017). Asteriks $\left(^{*}\right)$ indicate the presence of species.

Additional file 3: Table S2. The abundance of tabanids in the different sites of the different bioclimatic zones (2015-2017).

Additional file 4: Table S3. Checklist, classification and collection sites of tabanids of Cameroon reported between 1970 and 2017. Species indicated with an asterisk $\left(^{*}\right)$ are those identified between 2015 and 2017, which were not found in the list of tabanids of Cameroon reported by Ovazza et al. [23].

\section{Acknowledgements}

We are grateful to Dalida, Lebale, Hiol and Sieumeni for their assistance in the field. We equally thank CARPA, IRAD Wakwa and MSEG for providing Nzi, Biconical and Vavoua traps. A big thanks to the heads of MSEG (Dr Nchare, Dr Achiri and Mr Abah) for facilitating field transportation in most of our surveys. We are thankful for the grammatical corrections made by Prof. Peter Windsor.

\section{Authors' contributions}

SLS and GLYA conceptualized the study. SLS, JFM and AAK undertook collection of field data and species identification. AAK and SLS constructed all the Tabanidae distribution maps. SLS and AAK drafted the manuscript, and JFM and GLYA critically reviewed and edited subsequent drafts. All authors read and approved the final manuscript.

\section{Funding}

This study did not receive any specific funding, but benefited from the material, technical and logistic support of CARPA, IRAD and MSEG in Cameroon.

\section{Availability of data and materials}

All data generated or analysed during this study are included in this published article and its supplementary information files. The description of the Sevi trap that was used in this study for the first time is provided within Additional file 1: Text 1.

\section{Declarations}

Ethics approval and consent to participate

Not applicable.

\section{Consent for publication}

Not applicable.

\section{Competing interests}

The authors declare that they have no competing interests.

\section{Author details}

${ }^{1}$ Programme Onchocercoses Field Station Laboratory, Ngaoundéré, Cameroon. ${ }^{2}$ Département de Biologie et Ecologie Animale, Institut de Recherche en Ecologie Tropicale (IRET/CENAREST), Libreville, Gabon. ${ }^{3}$ Laboratoire d'Ecologie Vectorielle (LEV), Libreville, Gabon. ${ }^{4}$ Laboratoire de Biologie et Santé, UFR Biosciences, Université Félix Houphouët-Boigny, Abidjan, Côte d'Ivoire. ${ }^{5}$ Université Des Sciences et Techniques (USTM), Franceville, Gabon.

Received: 25 March 2021 Accepted: 23 July 2021

Published online: 09 August 2021

\section{References}

1. Pape T, Blagoderov V, Mostovski MB. Order Diptera Linnaeus, 1758. In: Zhang ZQ, editor. Animal biodiversity: an outline of higher-level classification and survey of taxonomic richness. Magnolia press, Zootaxa. 2011:3148:222-9.

2. Ježek J, Tkoč M, Van Harten A. Order Diptera, family Tabanidae. In: Harten A van, editor. Department of the President's Affairs, Arthropod fauna of the UAE. 2017;6:477-537.

3. Roskov Y, Kunze T, Paglinawan L, Orrell T, Nicolson D, Culham A, et al. Species 2000 \& ITIS catalogue of life, 2013 annual checklist. Catalogue of Life Annual Checklist. Technical report. Reading: Species 2000/ITIS; 2013.

4. Henriques AL, Krolow TK. Description of Muscotabanus gen. nov. and Muscotabanus rafaeli sp. Nov. (Diptera: Tabanidae, Diachlorini) from Amazon Basin, Brazil. Mem Inst Oswaldo Cruz. 2013;108:383-5.

5. Gorayeb IS. Tabanidae (Diptera) of Amazonia XXI. Descriptions of Elephantotus gen. n. and E. tracuateuensis sp. n. (Diachlorini) from the Brazilian coast. Zookeys. 2014;395:23-31.

6. González CR. The genus Acellomyia González, a new taxonomic arrangement of its species and descriptions of a new genus and two new species from southern South America (Diptera: Tabanidae: Diachlorini). Zootaxa. 2017:4337:523-9.

7. González CR. Buestanmyia chiriboga gen. nov. et sp. nov. (Diptera: Tabanidae: Diachlorini) from the Ecuadorian Andes. Zootaxa. 2021;4949:11.

8. Krinsky WL. Animal disease agents transmitted by horse flies and deer flies. J Med Entomol. 1976;13:225-74.

9. Foil LD, Hogsette JA. Biology and control of tabanids, stable flies and horn flies. Rev Sci Techniq. 1994;13:1125-58.

10. Baldacchino F, Desquesnes M, Mihok S, Foil LD, Duvallet G, Jittapalapong S. Tabanids: neglected subjects of research, but important vectors of disease agents! Infect Genet Evol. 2014;28:596-615.

11. Duvallet G, Boulanger N, Robert V. Arthropods: definition and medical importance. In: Boulangie N, editor. Skin and arthropod vectors. Amsterdam: Elsevier Inc; 2018; p. 29-51.

12. Zumpt F. Medical and veterinary importance of horse-flies. S Afr Med J. 1949:23:359-62.

13. Wells EA. The importance of mechanical transmission in the epidemiology of nagana: a review. Trop Anim Health Prod. 1972;4:74-88.

14. Mamoudou A, Mbanwei M, Fongho SP, Sevidzem SL, Farikou O, Rebecca $\mathrm{G}$, et al. Tabanids (Diptera: Tabanidae) fauna composition in different sites and biotopes of Far-North. Cameroon J Biol Nature. 2016;6(3):146-54.

15. Mounioko F, Maganga GD, Mavoungou JF, Zinga Koumba CR, Koumba AA, Sevidzem SL, et al. Molecular sScreening of Trypanosoma spp. in Glossina, Stomoxys and tabanids in the Moukalaba Doudou National Park (South-West, Gabon). World J Vet Sci. 2018;6:52-61.

16. Bitome-Essono P-Y, Ollomo B, Arnathau C, Durand P, Mokoudoum ND, Lauriane Yacka-Mouele L, et al. Tracking zoonotic pathogens using bloodsucking flies as 'flying syringes'. Elife. 2017;6:e22069.

17. Moeti OT, Makhosazanay YM, Namangala B, Amos C, Nthatisi IM, Musinguzi SP, et al. Characterization of tabanid flies (Diptera: Tabanidae) in South Africa and Zambia and detection of protozoan parasites they are harbouring. Parasitology. 2017;144(9):1162-78.

18. Zinga-Koumba RC, Bouyer J, Mavoungou JF, Acapovi-Yao GL, Kohagne $\mathrm{TL}$, Mbang Nquema $\mathrm{OA}$, et al. Evaluation de la diversité des diptères hématophages dans une clairière marécageuse du Gabon à l'aide des pièges Vavoua et Nzi. Rev Elev Med Vet Pays Trop. 2013;66(3):91-6.

19. Duke BOL. The development of Loa in flies of the genus Chrysops and the probable significance of the different species in the transmission of loasis Trans R Soc Trop Med Hyg. 1955;49(2):115-21.

20. Kouam MK, Kamgno J. The African Chrysops. In: Shields VDC, editor. Biological control of pest and vector insects. London: Intech Open; 2017; p. 286-298. https://www.intechopen.com/chapters/53824

21. Rageau J, Grenier P, Adam JP. Tabanidae du Cameroun français. Ann Parasitol Hum Camp. 1955;30(3):243-71.

22. Setser EA, Joy JE. Putative Sensory Structures Associated with the Food Canal of Hybomitra difficilis (Diptera: Tabanidae). Proc W Va Acad Sci. 2017:89(2):18-23.

23. Ovazza M, Mouchet J, Rickenbach A. Tabanidae du Cameroun: II. Les espèces connues et leur répartition. Cah. O.R.S.T.O.M., sér Ent mét et Parasitol. 1970;8(1):323-351. 
24. Itard J, Finelle P, Rickenbach A. Contribution à l'étude des Tabanides (Diptera) d'Afrique Centrale: les Tabanides de la République Centrafricaine. Rev Elev Med Vet Pays Trop. 1963;16(2):159-72.

25. Lydie AYG, Lendzele SS, Desquesnes M, Dia ML. An updated list of Tabanidae (Diptera: Insecta) in Ivory Coast. J Insect Biodiv Syst. 2017;3(1):69-79.

26. Surcouf MJ. Note sur les Tabanidae d'Algérie et de Tunisie. Arch Inst Pasteur Tunis. 1913;183-186.

27. Leclercq M, Maldès JM. Inventaire des Tabanidae d'Algérie et du Maroc et description d'une espèce nouvelle (Diptera, Brachycera). Nouv Rev Entomol (NS). 1987;4:79-84.

28. Zeghouma D, Bouslama Z, Duvallet G, Zuhair SA. Horse flies and their seasonal abundance in EI Tarf Province of northeastern Algeria. J Vector Ecol. 2018:43(2):305-11.

29. Jezek J, Oboňa J, Wamiti W, Njoroge N. Upswing of collections of horse flies (Diptera: Tabanidae) held at the National Museums of Kenya. Nairobi Acta Mus Siles Sci Natur. 2017;66:53-63.

30. Mugasa CM, Villinger J, Gitau J, Ndungu N, Ciosi M, Masiga D. Morphological re-description and molecular identification of Tabanidae (Diptera) in East Africa. ZooKeys. 2018;769:117-44.

31. Mavoungou JF, Makanga BK, Acapovi-Yao G, Desquesnes M, M'Batchi B. Chorologie des Tabanidae (Diptera) dans la réserve de biosphère IpassaMakokou (Gabon) en saison des pluies. Parasite. 2012;19:165-71.

32. Bitome-Essono PY, Dechaume-Moncharmont F-X, Mavoungou J, Mba RO, Duvallet G, Bretagnolle F. Distribution and abundance of hematophagous flies (Glossinidae, Stomoxys, and Tabanidae) in two national parks of Gabon. Parasite. 2015;22(23):1-11.

33. Lendzele SS, Abdoulmoumini M, Lydie AY. Spatial repartition of tabanids (Diptera: Tabanidae) in different ecological zones of North Cameroon. Biodiv Int J. 2017;1(2):64-8.

34. Fongho SP, Njiokou F, Garabed R, Mamoudou A, Arabi M, Malam AT. Etude préliminaire des vecteurs mécaniques potentiels des trypanosomes animaux dans la région de l'Extreme Nord du Cameroun. Rev Elev Med Vet Pays Trop. 2019;72(3):133-6.

35. Hiol V, Sieumeni AD, Mamoudou A, Sevidzem SL, Njan-Nloga AM, Nukenine EN. Spatio-temporal dynamics of Glossinidae, Tabanidae and Stomoxyidae around the Douala-Edea Wildlife Reserve in Cameroon. Am J Entomol. 2019;3(2):36-42.

36. Mamoudou A, Ikoum D, Sevidzem SL, Njan Nloga AM, Sieumeni Djoguep A, Mohammadou B, et al. Bovine trypanosomiasis and vectors in Lom and Djerem Division of East-Cameroon. African J Biol Sci. 2020;2(3):20-9.

37. Hribar LJ, Le Prince DJ, Foil LD. Design of a canopy trap for collecting horse flies (Diptera: Tabanidae). J Am Mosq Control Assoc. 1991;7(4):657-9.

38. Mihok S. The development of a multipurpose trap (the Nzi) for tsetse and other biting flies. Bull Entomol Res. 2002;92:385-403.

39. Laveissière C, Grébaut P. The trapping of tsetse flies (Diptera: Glossinidae). Improvement of a Model: the Vavoua Trap. Trop Med Parasitol. 1990:41(2):185-92.

40. Challier A, Laveissière C. Un nouveau piège pour la capture des Glossines (Glossina: Diptera, Muscidae) description et essais sur le terrain. Cah. O.R.S.T.O.M., sér Ent mét et Parasitol. 1973;11:251-262.

41. Votýpka J, Brzoňo J, Ježek J, Modrý D. Horse flies (Diptera: Tabanidae) of three West African countries: faunistic update, barcoding analysis and trypanosome occurrence. Acta Trop. 2019;197:105069.
42. Surcouf JMR, Ricardo G. Etude monographique des Tabanides d'Afrique (groupe des "Tabanus"). Paris: Masson et Cie; 1909.

43. Oldroyd H. The horse-flies of the Ethiopian Region (Diptera: Tabanidae). II. Tabanus and related genera. London: British Museum (Natural History); 1954.

44. Chainey JE, Oldroyd. Family Tabanidae. pp. 275-308. In: Crosskey RW, editor. Catalogue of the Diptera of the Afrotropical Region. London: British Museum (Natural History); 1980; p. 1437.

45. Oldroyd H. The horse-flies of the Ethiopian Region (Diptera: Tabanidae). III. Subfamilies Chrysopinae, Scepsidinae and Pangoniinae and a revised classification. London: British Museum (Natural History); 1957. p. 496.

46. JASP Team. JASP (version 0.14.1); 2020. https://jasp-stats.org. Accessed 23 June 2020.

47. Ahmed AB, Okiwelu SN, Samdi SM. Species diversity, abundance and seasonal occurrence of some biting flies in Southern Kaduna. Nigeria Afr J Biomed Res. 2005:8:113-8.

48. Surcouf J, Roubaud CE. Tabanides recueillis au Congo français par la mission d'études de la maladie du sommeil. Bull LWZZS Hist Nat Paris. 1908:5:221-5.

49. Leclercq M. Tabanidae (Diptera) du Liberia et d'autres pays africains RuZZ Znsf Agron Gembloux. 1965;33(l):135-137.

50. Sevidzem SL, Mamoudou A, Woudamyata AF, Zoli PA. Contribution to the knowledge of ecodiversity and density of tsetse (Glossinidae) and other biting flies (Tabanidae and Stomoxyinae) in the fly controlled-infested livestock/wild life interface of the Adamawa plateau-Cameroon. J Entomol Zool Stud. 2015;3:329-33.

51. Chvála M, Lyneborg L, Moucha J. The horseflies of Europe (Diptera, Tabanidae). Copenhagen: Entomological Society of Copenhagen; 1972.

52. Krčmar S. Ecological notes on Tabanus bromius L., and Haematopoto pluvialis (L.), (Diptera: Tabanidae) of some flood areas in Croatian sections of the river Danube. J Vector Ecol. 2004;29:376-8.

53. Dörge DD, Cunze S, Klimpel S. Incompletely observed: niche estimation for six frequent European horsefly species (Diptera, Tabanoidea, Tabanidae). Parasites Vectors. 2020;13:461.

54. Mounioko F, Mavoungou JF, Zinga-Koumba CR, Engo PE, Koumba AA, Maroundou AP, et al. Etude Préliminaire des vecteurs Mécaniques des trypanosomes dans la localité de Campo et ses environs (Sud-Ouest du Cameroon). Faunistic Entomol. 2017:70:95-105.

55. Tongue LK, Ngapagna AN. Emerging vector-borne diseases in Central Africa: a threat to animal production and human health. In: Claborn D, Bhattacharya S, Roy S. Current topics in the epidemiology of vectorborne diseases. London: Intech Open; 2019. p. 1-14.

56. Ziébé R, Thys E, De Deken R. Analyse de systèmes de production animale à l'échelle d'un canton: Cas de Boboyo dans l'Extrême-Nord Cameroun. Rev Elev Med Vet Pays Trop. 2005;58:159-65.

57. MINEPIA: MINEPIA Policy Document. Ministry of Livestock Fisheries and Animal Industries: Yaounde; 2013.

\section{Publisher's Note}

Springer Nature remains neutral with regard to jurisdictional claims in published maps and institutional affiliations.

Ready to submit your research? Choose BMC and benefit from

- fast, convenient online submission

- thorough peer review by experienced researchers in your field

- rapid publication on acceptance

- support for research data, including large and complex data types

- gold Open Access which fosters wider collaboration and increased citations

- maximum visibility for your research: over $100 \mathrm{M}$ website views per year

At BMC, research is always in progress.

Learn more biomedcentral.com/submissions 